Article

\title{
Why Do Czech Customers Come to Upper Palatinate? Motives, Sales Volume, and the Importance of Distance: A Case Study of Shopping in Bavaria
}

\author{
Matthias Segerer ${ }^{1}$, Dita Hommerová ${ }^{2}$ and Karel Šrédl ${ }^{3, * \mathbb{D}}$ \\ 1 IHK Regensburg für Oberpfalz/Kelheim, 93047 Regensburg, Germany; segerer@regensburg.ihk.de \\ 2 Department of Marketing, Trade and Services, Faculty of Economics, University of West Bohemia, \\ Univerzitní 8, 30614 Pilsen, Czech Republic; hommer@kmo.zcu.cz \\ 3 Department of Economic Theories, Faculty of Economics and Management, Czech University of Life \\ Sciences Prague, Kamýcká 129, 16500 Prague 6, Czech Republic \\ * Correspondence: sredl@pef.czu.cz; Tel.: +420-224-382-339
}

Received: 17 April 2020; Accepted: 4 May 2020; Published: 9 May 2020

\begin{abstract}
This case study investigates the cross-border shopping behavior and potential of Czech customers in Upper Palatinate (Bavaria). Based on a point of sale survey (POS) and two household surveys with more than 500 participants, the expenditures of Czech customers in the retail market in Upper Palatinate are estimated using linear potential methods. Using a logit model, the study also attempts to identify the main drivers of cross-border shopping, aiming at increasing its intensity and thus furthering the development of the cross-border region. The distance from the place of residence to the border is the strongest influencing variable, but demographic characteristics also impact the decision to go shopping in Bavaria. Finally, specific activities within the categories of "welcome culture" and "marketing and communication" aimed at promoting the cross-border shopping of Czech customers in Upper Palatinate are proposed. Local retailers should especially benefit from the frequency function of grocery stores as well as develop combination offers, e.g., with tourist facilities, following sustainable development trends.
\end{abstract}

Keywords: cross-border shopping; purchasing power; Czech consumers in Bavaria; logit regression; German-Czech border region; sustainable development

\section{Introduction}

The fall of the Iron Curtain changed not only the political map in Europe but also the economic exchanges. Above all, the border regions between Central and Eastern Europe were suddenly no longer on the edge but in the middle of Europe. The opening of borders also allowed increased cross-border activities, not only in the labor market but also in the exchange of goods and services. While geographic and regional economic theories tend to focus on general exchange relationships between countries or regions [1], the local and regional effects in the border regions have so far seen little research. In this context, retail is of particular importance. Mainly because of the price differences between different products across the border, retail is an important trigger for cross-border activities for the inhabitants of the border regions [2-4].

This is exactly the aim of this paper-presenting a model that identifies the influencing factors and explains cross-border purchasing activities between the Czech Republic and Germany, exemplified in the region of West Bohemia and East Bavaria.

This model is thus intended to provide important information on the question: Why do Czech customers come to East Bavaria to shop? Consequently, the study has important results expected to help companies and tourism organizations better understand the customer choice of cross-border shopping 
and thus derive the appropriate marketing measures, particularly in the area of communications and sales. For local political decision-makers, the study provides important information in the context of cross-border decisions, such as promoting further exchanges within the cross-border region.

\section{Literature Review}

In the vicinity of open borders in Europe and due to the prevalence of cross-border spaces, economic exchange increases. The relevance of this emerging economy is followed by processes of social exchange (in a now classic order of factors), creating new economic centers and new channels for the flow of commodities as well as people [5].

An important role in the development of border regions is that of "cross-border" regional politics. However, that has so far been a problem, as the often high-quality regional development programs stop at the border and do not take into account the neighboring region across the border, its strengths or weaknesses, or the possibility of positive as well as negative effects of the adjacent region (the diffusion or effect of potential differentiation). The economic situation-developed market economy, transforming or developing economy - has a decisive impact on the development of border regions. Different economic conditions on both sides of the border can cause problems concerning the coalescence of the region-the so-called "periphery or territory effect" [6]. This is also confirmed by Dokoupil, Matušková, Dittrich, Kottl, and Roosen [7], as well as by Jeřábek, Pohajdová, Raška [8].

Nowadays, more and more people travel around the world and engage in a variety of tourist activities, experiencing many places which differ from home. Tourist destinations, however, do not always have to be situated far away "on the other side of the world" but can also be located in geographical proximity and still be seen as attractive places to visit. Cross-border tourism and intraregional mobility, in particular, have increasingly come to the attention of researchers dealing with tourism [9].

Hampl [10] focuses on the problems of current tendencies differentiating between borderland and inland, and among border regions themselves. First, the borderland-inland differences are still limited, but they will probably deepen in the future. Second, the differences between border regions are important both in the intensity of settlement and on an economic level, and in current development dynamics. In his study from 2000, Hampl [10] evaluated the Czech Republic as a whole and predicted a future development that seems to have come true. The country's border regions are less densely populated compared to the inland area. Young people leave for large cities further inland to go to school and find jobs, and, given the openness of the Czech economy, some of them go abroad in search of job opportunities and rarely return. In the past 10-15 years, the economic potential of the German-Czech border region has been identified. Large German and multinational corporations, as well as small and medium-sized enterprises, have been establishing subsidiaries and setting up daughter companies on the Czech side of the border. This has led to the region coming alive and gaining in strength. Attractive new jobs have been created, and local communities' purchasing power has increased. These companies also engage in cooperation with secondary schools and universities in order to ensure a competent workforce for themselves. Examples of such companies include BMW, Siemens, ZF Engineering, Grammer, and others. This results in the development and economic growth of these regions.

Changes in local politics play a significant role in the development of services in border regions-the process of integration and social changes, particularly the increasing mobility of the population, the perception of the neighboring country, overcoming barriers (e.g., language), and others. The same changes also affect the retail sector, in which the major focus is on the customer/consumer. The retail segment is an important factor in economic growth [11]. With the power of government reduced, current urban tourism governance systems increasingly rely on local tourism policy networks. In these networks, different actors need to work together to achieve coherent destination management (decision-making and policies), which has made destination management increasingly complex [12]. 
In the case of "cross-border shopping in Germany", we have clear images in mind: Scandinavians buying cheap alcoholic beverages on the ferry, Germans refueling their cars in the Czech Republic or buying legal drugs in the Netherlands, or the Swiss who clear out the shops at the German border. However, the reality of cross-border trade is clearly "more boring" yet of enormous economic significance. In most cases, there are rational reasons for purchasing goods in the respective neighboring country. Consequently, countries with strong purchasing power, especially Denmark, the Netherlands, and Switzerland, have been subject to studies on cross-border retail. Since the political changes in Europe in the 1990s, neighbors from Poland and the Czech Republic-despite their markedly lower purchasing power compared to Germany-have also played an important role in the border region of East Bavaria. Cross-border retail has always been an important economic factor, as differences in market conditions give a significant monetary incentive-especially in terms of the fiscal framework-for purchasing across the border. In addition to these monetary incentives, a different selection to choose from, differences in quality, but also typical regional products as well as a more pleasant shopping atmosphere motivate consumers to go shopping over the border. Based on these fundamental motives, a qualitative study by the European Commission [3] distinguishes between the following cross-border shopping types:

- The "average consumers" who seldom or never do their shopping in other countries because of a lower income and level of education.

- The "cross-border purchasers" who do their shopping regularly and purposefully in other countries due to business travel and a higher income.

- The "residents of border regions" for whom it is partly natural to do their shopping on both sides of the border because of the geographical proximity.

In this article, the focus was placed on the regional effects of cross-border purchasing, hence on the "residents of the border region".

The changing behavior of Czech shoppers can be further reflected in the monitoring of shopping format preferences. Such a survey is periodically conducted by the company INCOMA Research [13].

There is the supplementary model by Teodorescu, Pargaru, Stancioiu, Matei, and Botos [14], who propose a systemic approach, the result of which refers to a model regarding the image research of a tourist destination, whose validation has been attained using the Transalpina destination. The model created by the authors envisages morphological features and specific functional relationships, which are consistent with the marketing theory, and, in the context, with the consumer behavior theory.

Despite the importance of this topic for the practice of regional development, hardly any scientific studies have been conducted on this topic so far. Previous contributions focused on high-purchasing border regions in Central and Western Europe, e.g., the Danish market [15,16], the Netherlands [9,17], Switzerland [18], and the border between the USA and Canada [19-21]. Only a few scientific studies are available for borders within Eastern Europe [22]. For border regions between Germany and the eastern EU states, such scientific studies are still lacking. Both practical and theoretical contributions show that the motive for purchases in the neighboring country has been sufficiently investigated: price, quality, and differing selection were identified as the main reasons for a shopping visit to a neighboring country. So far, however, there is still no approach that maps cross-border shopping behavior in its entirety, that is, why citizens drive from Country A to Country B for shopping.

\section{Materials and Methods}

\subsection{Formulation of the Problem}

So far, however, only a few regional studies have dealt with the subject of regional cross-border shopping (see Table 1). The focus in these studies is on customers who already use the German retail infrastructure and who were asked to make their assessment only in a point of sale survey (POS) survey. However, the following questions were not investigated: 
- Q1: Why do neighbors come across the border to shop in Upper Palatinate and why not (motive)?

- Q2: What is the turnover volume of retail in Upper Palatinate (sales volume)?

- Q3: What is the significance of the distance to the next shopping destination in coming to Upper Palatinate (evidence of distance)?

Table 1. Relevant publications on regional cross-border purchasing behavior.

\begin{tabular}{|c|c|c|c|c|c|c|}
\hline Author & Study Area & Type of Survey & Methodology & TURNC & MOT & DIST \\
\hline \multicolumn{7}{|c|}{ Scientific literature } \\
\hline Förster [23] & $\begin{array}{c}\text { CZ-GER <-> } \\
\text { Cheb/Markredwitz }\end{array}$ & $\begin{array}{l}\text { Point of Sale } \\
\text { license number } \\
\text { (car) }\end{array}$ & $\begin{array}{l}\text { Descriptive } \\
\text { analysis } \\
\text { Cartographical } \\
\text { analysis }\end{array}$ & $\mathrm{x}$ & $\checkmark$ & $(\checkmark)$ \\
\hline $\begin{array}{l}\text { Spierings and Van } \\
\text { der Velde [17] }\end{array}$ & $\begin{array}{c}\text { NL-GER <-> } \\
\text { Arnheim/Nimwegen } \\
\text { Aachen }\end{array}$ & Household survey & $\begin{array}{l}\text { Descriptive } \\
\text { analysis } \\
\text { Cartographical } \\
\text { analysis }\end{array}$ & $\mathrm{x}$ & $\checkmark$ & $(\checkmark)$ \\
\hline Köttl [24] & $\begin{array}{c}\text { CZ-GER -> } \\
\text { Northeast Bavaria }\end{array}$ & Household survey & $\begin{array}{c}\text { Descriptive } \\
\text { analysis }\end{array}$ & $(\checkmark)$ & $\checkmark$ & $\mathrm{x}$ \\
\hline \multicolumn{7}{|c|}{ Practice studies } \\
\hline $\begin{array}{c}\text { IHK Regensburg } \\
\text { für } \\
\text { Oberpfalz/Kelheim } \\
{[4]}\end{array}$ & $\begin{array}{l}\text { CZ-GER -> } \\
\text { Cham county }\end{array}$ & $\begin{array}{l}\text { Point of Sale } \\
\text { Experts survey }\end{array}$ & $\begin{array}{c}\text { Descriptive } \\
\text { analysis } \\
\text { Cartographical } \\
\text { analysis } \\
\text { Qualitative } \\
\text { analysis }\end{array}$ & $\mathrm{x}$ & $\checkmark$ & $(\checkmark)$ \\
\hline $\begin{array}{l}\text { IHK Chemnitz } \\
{[25]}\end{array}$ & CZ-GER<-> & Point of Sale & $\begin{array}{l}\text { Descriptive } \\
\text { analysis }\end{array}$ & $\mathrm{x}$ & $\checkmark$ & $(\checkmark)$ \\
\hline IHK Dresden [26] & $\begin{array}{l}\text { CZ-GER -> } \\
\text { Zittau }\end{array}$ & Point of Sale & $\begin{array}{l}\text { Descriptive } \\
\text { analysis } \\
\text { Cartographical } \\
\text { analysis }\end{array}$ & $\mathrm{x}$ & $\checkmark$ & $(\checkmark)$ \\
\hline Cimler et al. [2] & CZ-GER <-> & Point of Sale & $\begin{array}{c}\text { Descriptive } \\
\text { analysis }\end{array}$ & $\mathrm{x}$ & $\checkmark$ & $(\checkmark)$ \\
\hline $\begin{array}{c}\text { IHK München } \\
\text { für Oberbayern } \\
{[27]}\end{array}$ & $\begin{array}{c}\text { AUT-GER -> } \\
\text { Upper Bavaria, } \\
\text { Upper Austria, } \\
\text { Salzburg county, } \\
\text { Tirol }\end{array}$ & $\begin{array}{l}\text { Household survey } \\
\text { Point of Sale }\end{array}$ & $\begin{array}{l}\text { Descriptive } \\
\text { analysis }\end{array}$ & $\mathrm{x}$ & $\checkmark$ & $(\checkmark)$ \\
\hline $\begin{array}{c}\text { IHK Niederbayern } \\
\text { [28] }\end{array}$ & $\begin{array}{l}\text { CZ/AUT-BRD -> } \\
\text { Deggendorf } \\
\text { county, } \\
\text { Freyung-Grafenau } \\
\text { county, Passau } \\
\text { county, Rottal-Inn } \\
\text { county }\end{array}$ & Household survey & $\begin{array}{c}\text { Descriptive } \\
\text { analysis } \\
\text { Cartographical } \\
\text { analysis }\end{array}$ & $\checkmark$ & $\mathrm{x}$ & $\mathrm{x}$ \\
\hline $\begin{array}{l}\text { IHK Cottbus und } \\
\text { Arbeitgeberverband } \\
\text { Lebuser Land [29] }\end{array}$ & $\begin{array}{c}\text { POL-GER -> } \\
\text { City and county of } \\
\text { Cottbus, Forst } \\
\text { (Lausitz)/Guben/Burg } \\
\text { (Spreewald) }\end{array}$ & $\begin{array}{l}\text { Point of Sale } \\
\text { Expert survey }\end{array}$ & $\begin{array}{l}\text { Descriptive } \\
\text { analysis }\end{array}$ & $\mathrm{x}$ & $\checkmark$ & $\mathrm{x}$ \\
\hline
\end{tabular}

These questions are answered on the basis of two household surveys and a POS survey in the Upper Palatinate-Bohemian border area. Based on this information, the sales volume is estimated. Subsequently, a logit model is used to analyze the influence of different sociodemographic variables and of the distance to the border on the decision to shop in Bavaria. Finally, taking these results into account, concrete recommendations are given on how to activate additional turnover for retail in Upper Palatinate.

Neither the often discussed tax or pure income aspects (e.g., [30,31]), nor purely tourist-motivated shopping visits have been at the center of consideration in previous studies (e.g., [19]). In contrast, the 
following analysis focuses on the motives, the potential for sales, and the importance of distance for cross-border shopping. Table 1 provides an overview of contributions that are classified with regard to the three characteristics: potential estimation, the motives of visitors, and the importance of distance for a purchase. The overview clearly shows that previous studies were focused on motives. In some studies, the distance was also analyzed. However, these results are limited to the purely descriptive level. The depth of the analysis is extended in the present article by the use of a structure-based, multivariate model. At the same time, in accordance with the purchasing power stream analysis of IHK Niederbayern [28], an attempt is made to quantify the overall economic significance, i.e., the existing sales volume, and thus to make a retail turnover estimation.

\subsection{Database and Methodology}

In order to answer the research questions, data from three surveys are available. In May 2014, 500 households in the Czech districts of Marienbad, Eger, Tachau, Taus, Klattau, Pilsen, Pilsen North, and Pilsen South were contacted within computer-assisted telephone interviewing (CATI) for the study "Czech Customers-Opportunities for Trade". The relevant population in the area of study in West Bohemia was 454,745 inhabitants in 2013 (see Czech Statistical Office [32]), the average household size was 2.37 (e.g., MB Research [33]). In order to obtain the most representative survey result possible, a weighting according to the number of inhabitants of the district is taken at the total population of the study area when evaluating the survey results. Based on the telephone interviews in Cham, Furth im Wald, Lam, Regensburg, Waldsassen, and Weiden in Upper Palatinate, six cities were identified that are favored by Czech customers as a shopping destination. In June 2014, a point of sale survey (POS) was carried out in these cities. During the "toll discussion", an analogous telephone household survey $(\mathrm{HH})$ of 500 persons was carried out in August 2014. In addition to the first household survey, this survey allows for a clear assignment concerning the turnover estimation. An overview of the different surveys, as well as the assignment of the database to the research questions, is given in Table 2.

Table 2. Overview of the different databases.

\begin{tabular}{|c|c|c|c|}
\hline Type of Survey & Study Area, Location & Sample Size $(n)$ & Research Questions \\
\hline $\begin{array}{c}\text { CATI I } \\
\text { (regularly) }\end{array}$ & $\begin{array}{l}\text { West Bohemia (Marienbad, Eger, } \\
\text { Tachau, Taus, Klattau, Pilsen. }\end{array}$ & 500 & Q1 (Motive) \\
\hline $\begin{array}{c}\text { CATI II } \\
\text { (toll discussion) }\end{array}$ & Pilsen Nord und Pilsen Süd) & 500 & $\begin{array}{c}\text { Q1 (Motive) } \\
\text { Q2(Purchasing Power) } \\
\text { Q3 (Distance) }\end{array}$ \\
\hline POS & $\begin{array}{l}\text { Cham, Furth im Wald, Lam, } \\
\text { Regensburg, Waldsassen und } \\
\text { Weiden }\end{array}$ & 200 & $\begin{array}{c}\text { Q1 (Motive) } \\
\text { Q2 (Purchasing Power) } \\
\text { Q3 (Distance) }\end{array}$ \\
\hline
\end{tabular}

A graphical overview of the purchasing power in the study areas and the POS locations are presented in Figure 1. It clearly indicates that in the Czech border regions only, about half of the retail-relevant purchasing power is available compared to the German side.

The motivation of Czech visitors is to be identified by descriptive statistics based on these data. Then, a turnover estimation is performed based on empirically determined utilization rates, frequency, and available income in order to represent the importance of Czech customers for retail in Upper Palatinate. Finally, the significance of the distance is analyzed by descriptive statistics and visualization within maps-in analogy to previous investigations. In addition, a stepwise logit model is employed to provide new insights into the importance of distance compared to sociodemographic characteristics. 


\section{Cross-border region: Purchasing Power}

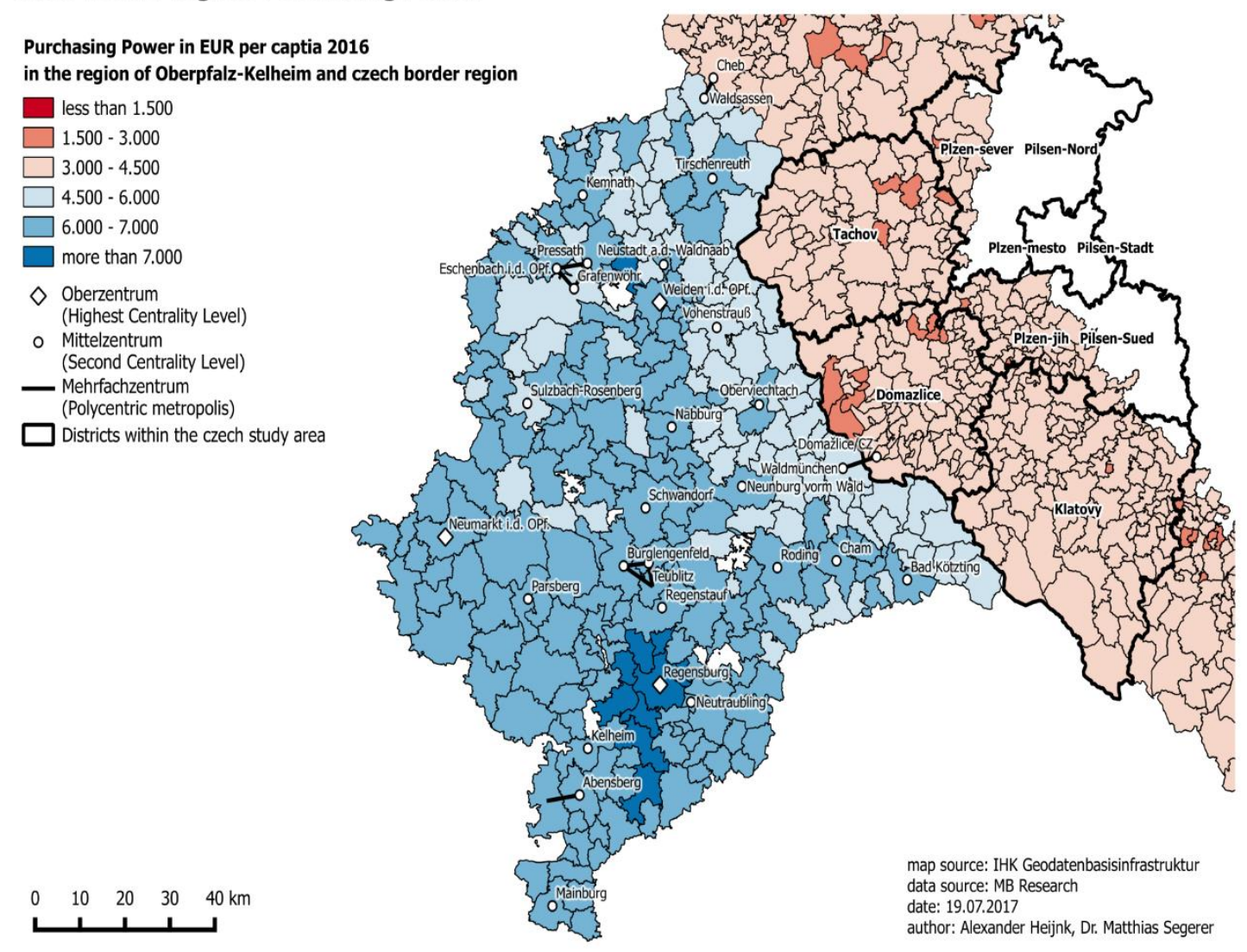

Figure 1. Characteristics of the study area.

\section{Results}

\subsection{Motives}

With a share of $46.3 \%$, almost every other Czech in the investigation area comes to Bavaria at least once a year (e.g., CATI II). The most important reason for visiting is shopping (see Figure 2).

In particular, the quality of supply, favorable prices, the different product offers, and the distance to the border can be identified as pull factors in this context (see Figure 3). These results match those from previous studies on cross-border shopping in East Bavaria and West Bohemia: not price but quality and service are the main reasons for shopping beyond the Czech border. At the same time, however, Figure 3 also illustrates that distance is the main reason why Czech neighbors do not come to Bavaria for shopping. The language and the same offer in the Czech Republic were named as further important reasons. The latter illustrates that the retail structure in the Czech Republic is gradually adapting to the German level. 


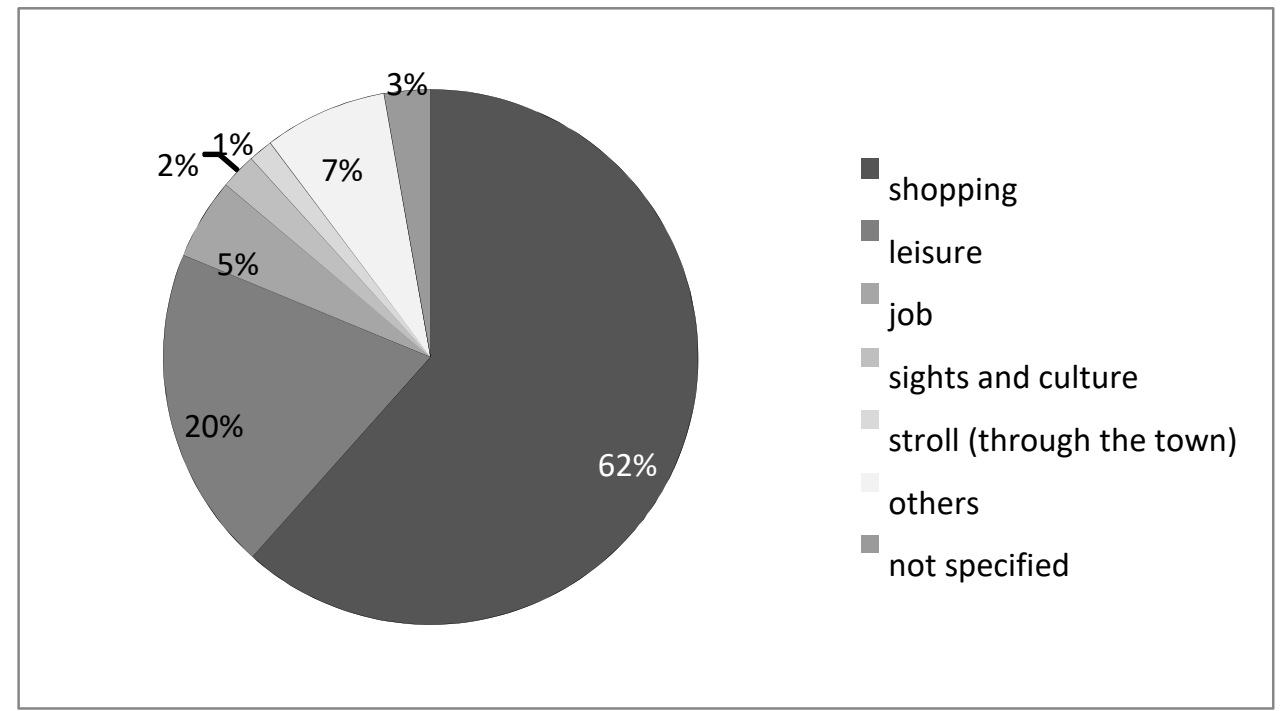

Figure 2. Main reasons for visiting Bavaria-CATI I (computer-assisted telephone interviewing; calculations according to [34], $n=310$ ).

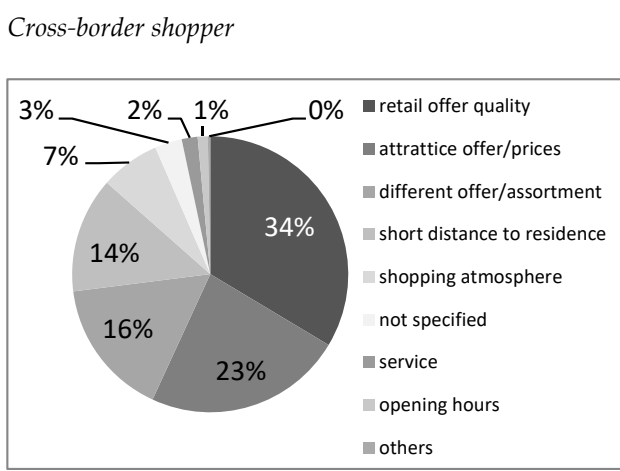

(a)
Non-User

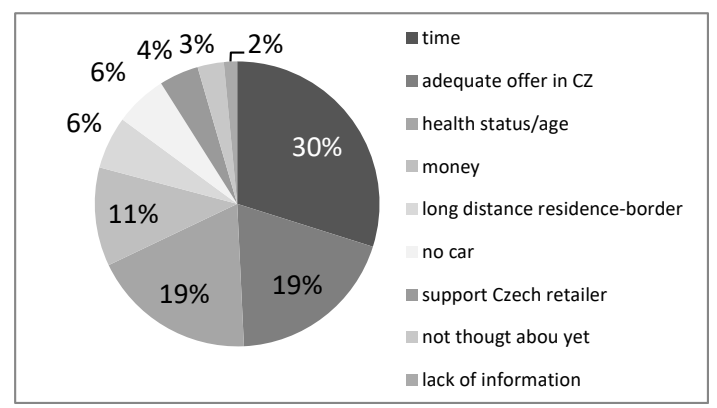

(b)

Figure 3. Reasons for cross-border shopping or non-cross-border activities in Bavaria-CATI I (calculations according to [34], $n=134$ and $n=692$, multiple nominations, (a) cross-border shopper and (b) non-user).

When doing their shopping in Germany, consumers mainly purchase items for short-term and medium-term use (see Figure 4). In particular, food markets and drugstores are favored by customers and thus serve as footfall generators.

Czech customers also use an attractive variety of goods in the fashion and shoe sectors on the Bavarian side. These goods of medium-term needs are in demand, especially in the centers of the first or second hierarchy level, such as Weiden and Cham, whereas goods of short-term needs are mainly in demand close to the border (see IHK Regensburg für Oberpfalz/Kelheim [35] and Figure 5). This result of the POS survey is also reflected in the household survey (CATI I): the spatial distribution of demand as a whole demonstrates that consumers from West Bohemia particularly target the border region of Marktredwitz along motorway A93 and national road B22 to Cham (see the hatched area in Figure 5). Apart from the nearby border cities, Cham, Regensburg, and Weiden are in the focus of Czech consumers. 


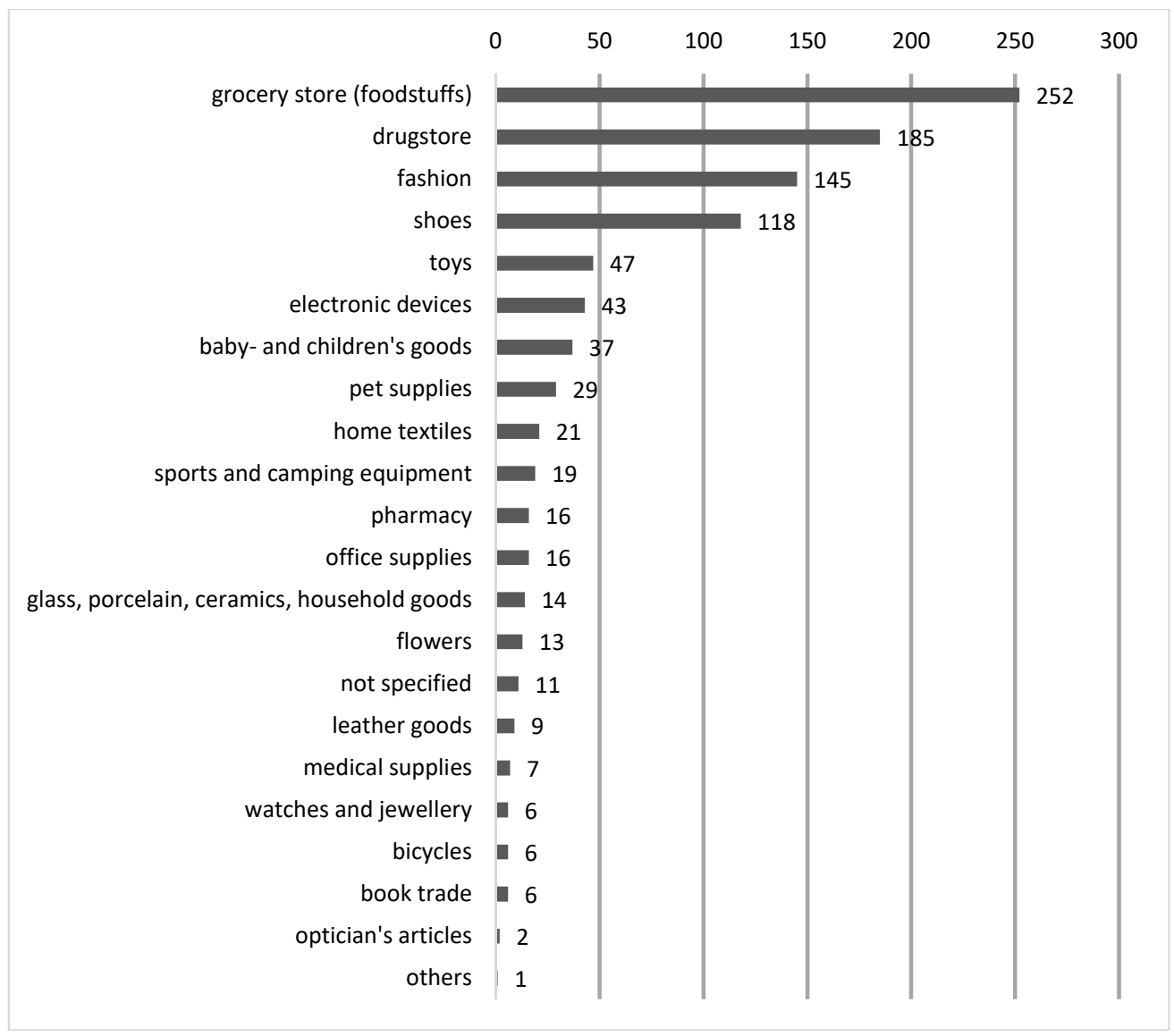

Figure 4. Preferred products of Czech customers-a point of sale survey (POS; calculations according to [34], $n=343)$.

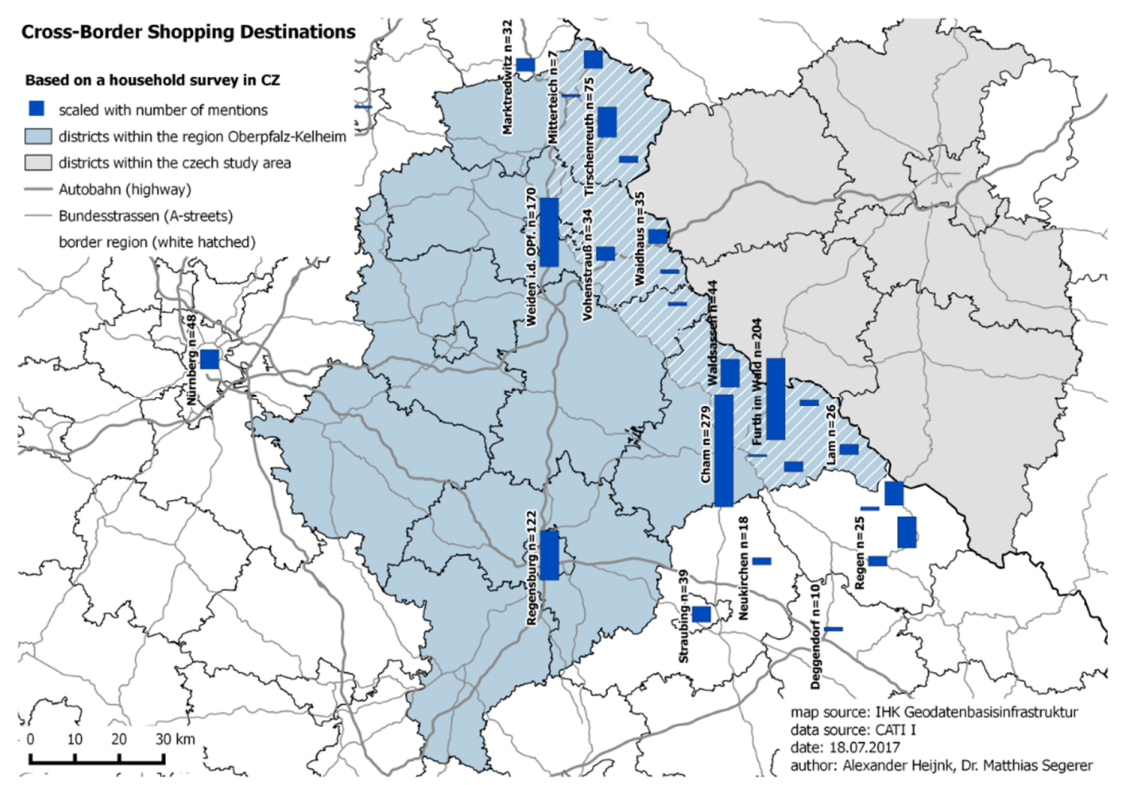

Figure 5. Destinations of consumers from West Bohemia-author's own design, according to CATI.

Now we know about the motivation and the spatial interaction pattern, but we do not know what a cross-border shopper looks like. Table 3 gives an overview of the characteristics that differentiate a User and Non-User-the former divided according to the results of the POS and household survey. The results for the CATI are as follows: 
- While the distribution of the variable Gender is almost identical in both groups, the distributions of Income and Age are different.

- The percentage of households with a higher income (over CZK 30,000) is $48.6 \%$ for the User and only $36.2 \%$ for the Non-User.

- The distribution of Age is different for the two groups. Almost $60 \%$ of Users are aged between 30 and 59 years, compared to only $45 \%$ of Non-Users. In the class of 18 to 29 years, exactly the opposite can be observed. This age class comprises only $18.1 \%$ of Users, compared to $32.3 \%$ of Non-Users.

Table 3. Sociodemographic characteristics of cross-border shoppers-CATI II $(n=501)$, POS $(n=310)$.

\begin{tabular}{cccc}
\hline & \multicolumn{2}{c}{ Cross-Border Shopper } & Non-Cross-Border Shopper \\
\hline & (User, POS) & (User, CATI II) & (Non-User) \\
\hline Gender & & & \\
\hline female & $52.1 \%$ & $53.4 \%$ & $53.9 \%$ \\
male & $44.2 \%$ & $46.6 \%$ & $46.1 \%$ \\
\hline Income & & & \\
\hline Up to CZK 20,000 & $12.8 \%$ & $21.4 \%$ & $31.7 \%$ \\
CZK 20,000 to & $25.9 \%$ & $30.0 \%$ & $32.1 \%$ \\
30,000 & & & \\
CZK 30,000 to & $28.9 \%$ & $23.2 \%$ & $19.5 \%$ \\
40,000 & $32.4 \%$ & $25.4 \%$ & $16.7 \%$ \\
CZK 40,000+ & & & \\
\hline Age & $14.3 \%$ & $18.1 \%$ & $32.3 \%$ \\
\hline $18-29$ & $38.8 \%$ & $29.3 \%$ & $21.2 \%$ \\
$30-44$ & $23.4 \%$ & $30.6 \%$ & $22.7 \%$ \\
$45-59$ & $15.0 \%$ & $22.0 \%$ & \\
$60+$ & & & \\
\hline
\end{tabular}

The results of the POS survey differ slightly but are probably more important because they are based on actual behavior and not anticipated behavior, as in the household survey. In other words, Users get caught "in flagranti". Within the POS survey, the percentage of rich households (CZK 30,000 or more) is higher than that in CATI II, and the observed distribution of age classes also differs. The majority of respondents are aged between 30 and 44 years.

To summarize, the cross-border shopper is characterized by above-average income and age between 30 and 59. Also, a higher proportion of women could be observed.

\subsection{Sales Volume}

Based on the information from the household survey (CATI II), 46.3\% of West Bohemians come to Bavaria for shopping, and with information on average expenditures from the POS survey, it is possible not only to identify the reasons why Czech customers come to Bavaria but also how much money they spend there. According to Equation (1), the overall sales volume (SV) which flows from West Bohemia to Bavaria (CZ-BV) is based on the proportion (Prop) of users from West Bohemia in the visits of all respondents in the survey and their frequency $(\mathrm{j})$, multiplied by the average expenditures (EXP), the number of visits per year for retail sales (NV), and the number of households (HH) (Total number of households in the study area $=189,477)$ :

$$
S V_{C Z-B V}=\sum_{j=1}^{n} \operatorname{Prop}_{j} \times H H \times E X P_{j} \times N V_{j}
$$


In sum, EUR 136.4 million flows from West Bohemia to Bavaria. Using the spatial distribution of the cross-border activities from Figure 5 as an indicator, about EUR 95 million worth of goods are purchased in Upper Palatinate. Of course, the county of Cham, as well as the cities of Weiden and Regensburg, benefit most from the inflow of purchasing power within this region. Regarding the overall retail purchasing power in the West Bohemian study area of about EUR 1.4 billion, it means that about $10 \%$ flows out to Bavaria.

\subsection{Distance}

A Google API was used to calculate the distances between the starting point (residence) and the shopping destination. For the POS survey, the routing distance was estimated, whereas for CATI II, the linear distance and the routing time were additionally calculated.

\subsubsection{Descriptive Analysis}

The average distance which cross-border shoppers cover is about $66 \mathrm{~km}$. However, this result is biased because the cross-border frequency is disregarded. Table 4 shows the percentile distribution of the routing distance weighted by frequency. Over $50 \%$ of the cross-border activities involve a distance of less than $22 \mathrm{~km}$ (see Table 5). Thus, the purchasing power outflow is not the same over the whole study area but increases with proximity to the border. The descriptive analysis of the routing distance classified by frequency confirms this result (see Table 6). The covered distance is inversely proportional to cross-border shopping frequency. This demonstrates that cross-border shopping is dominated by the local cross-border traffic, and thus the main purchasing power flow is located within approximately $30 \mathrm{~km}$ of the border (see the hatched area in Figure 6).

Table 4. Estimation of the sales volume of Czech customers in Bavaria-author's own calculations, according to POS and CATI II.

\begin{tabular}{|c|c|c|c|c|c|}
\hline Frequency $(j)$ & $\begin{array}{c}\text { Proportion Frequency } \\
\text { Category (Prop) })_{\mathrm{j}} \text { in Overall } \\
\text { Frequency of Users } \\
\text { (Prop) }\end{array}$ & $\begin{array}{l}\text { Number of } \\
\text { Households } \\
\text { (HH) }\end{array}$ & $\begin{array}{c}\text { Expenditure } \\
\text { Per Visit } \\
\left(\text { EXP }_{\mathbf{j}}\right) \text { in EUR }\end{array}$ & $\begin{array}{l}\text { Number of } \\
\text { Visits Per Year } \\
\left(\mathrm{NV}_{\mathbf{j}}\right)\end{array}$ & $\begin{array}{c}\text { Sales Volume Per } \\
\text { Year } \\
\emptyset^{1}\left(S_{j}\right) \text { in EUR }\end{array}$ \\
\hline $\begin{array}{l}\text { several times a } \\
\text { week }\end{array}$ & $8.6 \%$ & 7583 & 54 & 104 & $42.6 \mathrm{~m}$ \\
\hline once a week & $10.4 \%$ & 9107 & 108 & 52 & $51.2 \mathrm{~m}$ \\
\hline once a month & $32.7 \%$ & 28,683 & 107 & 12 & $36.8 \mathrm{~m}$ \\
\hline $\begin{array}{l}\text { once every six } \\
\text { months }\end{array}$ & $31.1 \%$ & 27,279 & 90 & 2 & $4.9 \mathrm{~m}$ \\
\hline once a year & $17.2 \%$ & 15,060 & 62 & 1 & $0.9 \mathrm{~m}$ \\
\hline \multicolumn{5}{|c|}{ Sum (SV $\left.{ }_{C Z-B V}\right)$} & $136.4 \mathrm{~m}$ \\
\hline
\end{tabular}

Table 5. Percentile analysis of the distance (weighted by annual frequency)—author's own calculations, according to POS $(n=199)$.

\begin{tabular}{lccccccc}
\hline & \multicolumn{6}{c}{ Percentile } \\
\cline { 2 - 8 } & $\mathbf{5}$ & $\mathbf{1 0}$ & $\mathbf{2 5}$ & $\mathbf{5 0}$ & $\mathbf{7 5}$ & $\mathbf{9 0}$ & $\mathbf{9 5}$ \\
\hline routing distance $(\mathrm{km})$ & 11.02 & 11.02 & 11.02 & 21.83 & 62.87 & 453.59 & 453.59 \\
\hline
\end{tabular}


Table 6. Routing distance of cross-border shopper (not weighted)—author's own calculations, according to POS.

\begin{tabular}{ccccccc}
\hline & N & Mean & Standard Deviation & Standard Error & Min. & Max. \\
\hline several times a week & 20 & 28.21 & 47.35 & 10.59 & 1.32 & 219.07 \\
once a week & 63 & 44.44 & 62.48 & 7.87 & 11.02 & 453.59 \\
once a month & 93 & 66.10 & 67.25 & 6.97 & 11.02 & 453.59 \\
once every six months & 17 & 127.46 & 60.56 & 14.69 & 11.02 & 210.17 \\
once a year & 4 & 246.28 & 119.10 & 59.55 & 102.35 & 352.75 \\
no information & 2 & 232.30 & 312.94 & 221.29 & 11.02 & 453.59 \\
\hline Sum & $\mathbf{1 9 9}$ & $\mathbf{6 5 . 9 7}$ & $\mathbf{7 8 . 0 9}$ & $\mathbf{5 . 5 4}$ & $\mathbf{1 . 3 2}$ & $\mathbf{4 5 3 . 5 9}$ \\
\hline
\end{tabular}

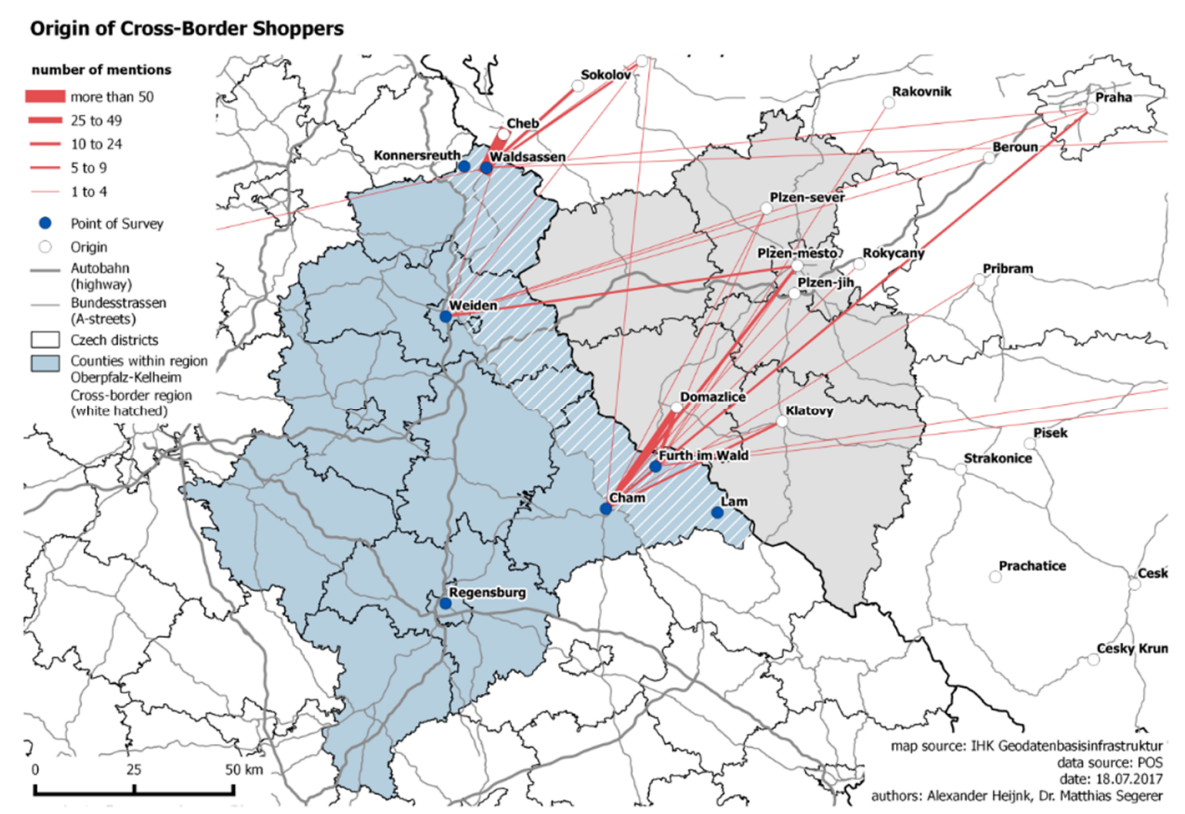

Figure 6. Distance matrix of Czech consumers in Bavaria.

\subsubsection{Univariate Regression}

Using the SPSS 21 curve fit mode, the linear, routing, and time distance (For type of measurement, see Table 7.) $\left(\mathrm{x}_{1}\right)$ is regressed on the frequency of cross-border shopping $(\mathrm{F})$, which is measured by the aggregated frequency per postal code area standardized by the number of observed cases (Due to model restrictions, the postal code areas with no cross-border shoppers were eliminated.). The best curve fit can be achieved with the exponential regression model applying linear distance to the next local community in Bavaria (see Figure 7):

$$
\begin{gathered}
F=\beta_{0}\left(e^{\left(\beta_{1} x_{1}\right)}\right) \\
\hat{F}=23.6\left(e^{\left(-0.43 x_{1}\right)}\right)
\end{gathered}
$$


Table 7. Descriptive statistics—author's own calculations, based on CATI II.

\begin{tabular}{|c|c|c|c|c|c|c|}
\hline Symbol & $\mathbf{N}$ & Min. & Max. & Mean & $\begin{array}{l}\text { Standard } \\
\text { Deviation }\end{array}$ & $\begin{array}{l}\text { Number of } \\
\text { Records }\end{array}$ \\
\hline \multicolumn{7}{|c|}{ Cross-border } \\
\hline yes & 466 & & & & & 221 \\
\hline no & 466 & & & & & 246 \\
\hline Persons per household & 466 & 1 & 9 & 2.72 & 1.172 & \\
\hline Under 18 & 466 & 0 & 4 & 0.51 & 0.824 & \\
\hline \multicolumn{7}{|c|}{ Distance } \\
\hline linear dist. next location & 466 & 5.97 & 68.46 & 38.56 & 20.39 & \\
\hline routing dist. next location & 466 & 7.65 & 98.47 & 53.74 & 25.58 & \\
\hline routing time next location & 466 & 9.93 & 83.00 & 52.71 & 22.00 & \\
\hline linear dist. centr. location & 466 & 8.52 & 74.94 & 45.50 & 20.41 & \\
\hline routing dist. centr. location & 466 & 13.32 & 109.38 & 55.50 & 21.24 & \\
\hline routing time centr. location & 466 & 15.55 & 91.92 & 55.88 & 20.20 & \\
\hline \multicolumn{7}{|c|}{ Income } \\
\hline Below CZK 20,000 & 466 & & & & & 124 \\
\hline CZK 20,000 to 30,000 & 466 & & & & & 145 \\
\hline CZK 30,000 to 40,000 & 466 & & & & & 99 \\
\hline CZK $40,000+$ & 466 & & & & & 97 \\
\hline \multicolumn{7}{|c|}{ Age } \\
\hline $18-29$ & 466 & & & & & 120 \\
\hline $30-44$ & 466 & & & & & 118 \\
\hline $45-59$ & 466 & & & & & 120 \\
\hline $60+$ & 466 & & & & & 108 \\
\hline \multicolumn{7}{|c|}{ Gender } \\
\hline Female & 466 & & & & & 253 \\
\hline Male & 466 & & & & & 213 \\
\hline
\end{tabular}

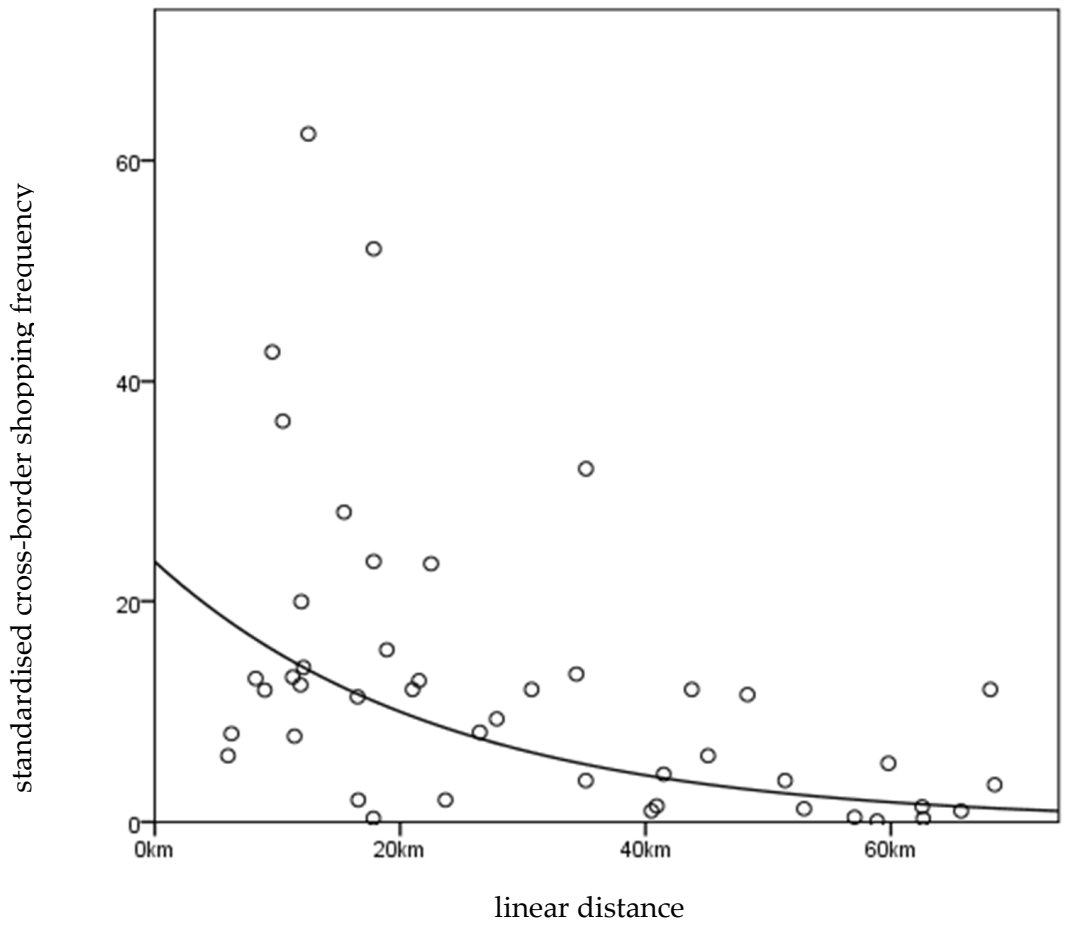

Figure 7. Distance matrix of Czech consumers in Bavaria. 
The influence of distance on cross-border shopping frequency is highly significant; the overall fit of the model with $R^{2}=0.33$ can be classified as satisfying to good. In accordance with the descriptive statistics, the exponential curve shape shows the cross-border shopping frequency decreasing with increasing distance. On the one hand, this result suggests that distance plays an important role in the decision to come to Bavaria for shopping, and on the other hand that the cross-border potential is determined by the demand potential close to the border on the Bohemian side.

\subsubsection{Binary Logit Model}

Finally, the descriptive and univariate distance analyses are transformed into a multivariate model approach. In accordance with models on the traffic mode selection, a binary logit model is used to predict the probability of cross-border shopping as well as to identify significant, influential variables. As evident from Equation (4), the binary logit model does not predict a certain value, but rather the probability (PCBS) that an interviewed person shops in Bavaria. Using a logistic link function, the probability results from a transformed regression analysis (see Equation (3)).

$$
P_{C B S}=\frac{e^{\beta_{0}+\beta_{1} x_{1}+\ldots \beta_{i x_{i}}}}{1-e^{\beta_{0}+\beta_{1} x_{1}+\ldots \beta_{i x_{i}}}}
$$

For a cross-border model, the distance (linear, routing distance, or time distance from the Czech postal code area to the next Bavarian community), as well as sociodemographic variables (age, household size, number of children, income, and gender), are used as predictors. Concerning the distance, three different calculation categories and two different destination types are applied. Distance is calculated with the Google API and is differentiated into

- linear distance, which means the beeline distance.

- routing distance, which means driving $\mathrm{km}$ by car.

- routing time, which means driving minutes by car.

The purpose of employing the model is to identify the main influence variable, so a step-wise approach using Wald forward selection is used.

Two different destination types are outlined:

- next location represents the distance from the place of residence to the next local community on the Bavarian side.

- next central location denotes the distance from the place of residence to a bigger town in Bavaria, which is classified in the highest ("Oberzentrum") or second hierarchy level ("Mittelzentrum") of regional planning.

Descriptive statistics of the input variables are presented in Table 7. The percentage of cross-border shoppers differs slightly to the one presented in Section 3.1 because cases without values for the variable "income" were excluded due to model restrictions. The descriptive statistics show that the average household size in the sample (2.72) is slightly higher than the Czech average (2.37 in 2014; e.g., MB Research 2014), while the monthly income is similar to the national average of about CZK 38,700 (e.g., MB Research [35], OECD [36], and author's own calculation), as the categorized nominations show. Due to missing comparative values regarding the used classification, a comparison of age in the sample with the values of the entire Czech Republic is difficult. The sample exhibits a slightly higher share of women in terms of the variable gender.

The variables of distance to the next central location, income, and age are identified as relevant predictors for the cross-border shopping decision. In all these three models, the variable distance to the next central location turned out to be the dominating predictor. The overall model fit with a Nagelkerke $\mathrm{R}^{2}$ value of 0.220 can be classified as mediocre to good (see Table 8). This is also confirmed by the classification table. While the null model predicts $52.7 \%$ categorized correctly (i.e., the base rate), the final model with three predictors classifies $68.3 \%$ of cases correctly (see Table 9 ). 
Table 8. Model summary of the step-wise binary logit regression-author's own calculations based on CATI II.

\begin{tabular}{|c|c|c|c|c|c|c|}
\hline \multicolumn{3}{|c|}{ Model Summary } & \multicolumn{4}{|c|}{ Tests of Model Coefficients } \\
\hline Model & Nagelkerke $R^{2}$ & ${ }^{1}$ Std. Error of the Estimate & & Chi Square & ${ }^{2} \mathrm{df}$ & ${ }^{3}$ Sig \\
\hline \multirow{3}{*}{ Step 1} & \multirow{3}{*}{0.154} & \multirow{3}{*}{0.4398} & Step & 57.297 & 1 & 0.000 \\
\hline & & & Block & 57.297 & 1 & \\
\hline & & & Model & 57.297 & 1 & \\
\hline \multirow{3}{*}{ Step 2} & \multirow{3}{*}{0.187} & \multirow{3}{*}{0.4347} & Step & 12.947 & 3 & 0.000 \\
\hline & & & Block & 70.244 & 4 & \\
\hline & & & Model & 70.244 & 4 & \\
\hline \multirow{3}{*}{ Step 3} & \multirow{3}{*}{0.220} & \multirow{3}{*}{0.4307} & Step & 13.932 & 3 & 0.000 \\
\hline & & & Block & 84.176 & 7 & \\
\hline & & & Model & 84.176 & 7 & \\
\hline
\end{tabular}

${ }^{1}$ Std. $=$ standard error. ${ }^{2} \mathrm{df}=$ degrees of freedom. ${ }^{3} \mathrm{Sig}=$ significance.

Table 9. Classification table of the step-wise binary logit regression-author's own calculations based on CATI II.

\begin{tabular}{|c|c|c|c|c|c|}
\hline & \multirow{3}{*}{ Model Observed } & & \multicolumn{3}{|c|}{ Predicted } \\
\hline & & & \multicolumn{2}{|c|}{ Cross-Border Shopper } & \multirow{2}{*}{ Percentage Correct } \\
\hline & & & No & Yes & \\
\hline \multirow{3}{*}{ Step 1} & \multirow{2}{*}{ cross-border shopper } & No & 173 & 73 & 70.3 \\
\hline & & Yes & 82 & 139 & 62.8 \\
\hline & \multicolumn{2}{|c|}{ Overall Percentage } & & & 66.7 \\
\hline \multirow{3}{*}{ Step 2} & \multirow{2}{*}{ cross-border shopper } & No & 191 & 54 & 78.0 \\
\hline & & Yes & 93 & 128 & 57.9 \\
\hline & \multicolumn{2}{|c|}{ Overall Percentage } & & & 68.4 \\
\hline \multirow{3}{*}{ Step 3} & \multirow{2}{*}{ cross-border shopper } & No & 175 & 71 & 71.1 \\
\hline & & Yes & 77 & 144 & 65.2 \\
\hline & \multicolumn{2}{|c|}{ Overall Percentage } & & & 68.3 \\
\hline
\end{tabular}

An analysis of variables identified the following predictors for the probability of shopping in Bavaria (see Table 10):

- Distance to the next central location: The negative sign underlines the results of the descriptive statistics. The probability of coming to Bavaria for shopping decreases with increasing distance.

- Income: A significant positive influence on cross-border shopping activities is observed for the higher income classes (CZK 30,000 to 40,000 and over CZK 40,000) compared to the reference category (less than CZK 20,000). This again shows that higher income increases the probability of coming to Bavaria for shopping.

- Age: While the direction of influence of the two other variables is as expected, the influence of age is contrary to expectation. All three categories ( 30 to 44,45 to 59 , and over 60 ) have a significant positive influence on the decision to come to Bavaria. This result is surprising, especially for the group of over 60-year-olds, as a negative influence due to mobility and income restrictions was expected. Also, the results of the POS survey suggest that there is no significance in the $60+$ category (see Table 3). 
Table 10. Variables in the equation-author's own calculations based on CATI II.

\begin{tabular}{|c|c|c|c|c|c|c|c|}
\hline & & B & S.E. & Wald & df & Sig. & $\operatorname{Exp}(B)$ \\
\hline \multirow{2}{*}{ Step 1} & linear dist. centr. location & -0.036 & 0.005 & 51.959 & 1 & 0.000 & 0.965 \\
\hline & Constant & 1531 & 0.248 & 37.991 & 1 & 0.000 & 4.623 \\
\hline \multirow{6}{*}{ Step 2} & Income & & & 12.582 & 3 & 0.006 & \\
\hline & CZK 20,000 to 30,000 & 0.265 & 0.266 & 0.994 & 1 & 0.319 & 1.303 \\
\hline & CZK 30,000 to 40,000 & 0.643 & 0.294 & 4.778 & 1 & 0.029 & 1.901 \\
\hline & CZK $40,000+$ & 0.980 & 0.297 & 10.870 & 1 & 0.001 & 2.665 \\
\hline & linear dist. centr. location & -0.038 & 0.005 & 53.584 & 1 & 0.000 & 0.963 \\
\hline & Constant & 1.185 & 0.298 & 15.774 & 1 & 0.000 & 3.271 \\
\hline \multirow{10}{*}{ Step 3} & AGE & & & 13.314 & 3 & 0.004 & \\
\hline & $30-44$ & 0.914 & 0.291 & 9.850 & 1 & 0.002 & 2.493 \\
\hline & $45-59$ & 0.935 & 0.293 & 10.181 & 1 & 0.001 & 2.548 \\
\hline & $60+$ & 0.821 & 0.324 & 6.439 & 1 & 0.011 & 2.273 \\
\hline & INCOME & & & 15.141 & 3 & 0.002 & \\
\hline & CZK 20,000 to 30,000 & 0.316 & 0.285 & 1.231 & 1 & 0.267 & 1.371 \\
\hline & CZK 30,000 to 40,000 & 0.771 & 0.320 & 5.813 & 1 & 0.016 & 2.162 \\
\hline & CZK 40,000+ & 1.174 & 0.326 & 12.990 & 1 & 0.000 & 3.234 \\
\hline & linear dist. centr. location & -0.037 & 0.005 & 50.248 & 1 & 0.000 & 0.964 \\
\hline & Constant & 0.392 & 0.381 & 1.061 & 1 & 0.303 & 1.480 \\
\hline
\end{tabular}

\subsection{Research Limitations}

Although the combination of three surveys (one POS and two household surveys) constitutes a substantial database sufficient to answer the research questions addressed in this study, the results are subject to some content caution and methodological restrictions.

- Several datasets: As the former original target of the investigation was not to observe the planned highway toll, the household surveys (CATI I and CATI II) differ slightly regarding the exact questioning and variable categories.

- Distribution of sales volume within the study area: Respondents within a household survey cannot provide information for all retail expenditures in Bavaria. Thus, the distribution of the sales volume in Bavaria is based on the indicator "frequency of the nomination of locations".

- Identification of Czech consumers and the influence of locality: How to identify Czech consumers at the POS? That was the question we asked ourselves, too. Hence, it is important to find locations where the car license plate can be identified. In this context, large parking lots are available in front of supermarkets or in central locations. However, consumer behavior is also influenced by the characteristics of the interview location. Customers who park their car in front of a supermarket are expected to be buying groceries, whereas customers who park near the town center are expected to be buying fashion clothing and shoes.

- Overall quality of the model: The goodness-of-fit of the overall "cross-border shopping" model is mediocre to good. This suggests that variables other than distance and sociodemographic characteristics could significantly influence the decision to travel across the border for shopping.

\section{Discussion}

The study shows that Bavaria is already a very popular shopping destination among Czech customers. Still, a majority of the interviewed households in West Bohemia do not consider traveling to shop in Bavaria (i.e., Upper Palatinate). Both the descriptive and the multivariate analyses demonstrate that the decision on cross-border shopping is mainly determined by the distance to the border. Additionally, age and income have a significant impact on cross-border activities. 
Nanengast, Linzmajer, Boettger, and Rudolph [37] say that consumers who attribute price differences to internal causes (i.e., national retailers) feel less conflicted than consumers who attribute the price differences to external causes (i.e., the foreign economy). These results have important implications for local retailers and public policymakers. Cross-border shopping behavior can be influenced by actively communicating the reasons for price differences between neighboring countries.

"According to Shopping Monitor 2005/6, Czechs like to shop; they do not mind the time spent in shops and they carefully choose the shops they visit. Another foreign market survey [13] states that Czechs have a high shopping IQ-especially in comparison to other Central European nations, respectively, to the other former Eastern Bloc countries. Thus they act economically and are able to gather the necessary information in the pre-sale phase. It is therefore clear that Czechs accept "western" modes of behavior more quickly than other Central European nations. They attach more importance to retailers' leaflets and are more sensitive to advertising in general" [13].

With a focus on the spatial radius of cross-border activities, it can be concluded that a radius of $30 \mathrm{~km}$ around the border is the main target area of consumers from West Bohemia. For Upper Palatinate, this means that first and foremost centers of the first or second hierarchy level from Marktredwitz to Weiden (along motorway A93), along the B22 national road to Cham and along the B85 national road to Miltach/Bad Kötzting can profit from the purchasing power potential of Czech customers. In this context, grocery markets and drugstores can act as a visitor magnet on the retail supply side, but centers of the first and second hierarchy level also attract Czech shoppers due to their score with their range of products on fashion clothing and shoes. These kinds of shops should be used as "traffic generators" for the city or location marketing:

- Synergies: Smaller specialist shops and service providers can benefit from this frequency function.

- Combination offers: The local providers should make joint offers. In grocery stores, discount vouchers could be issued for other local shops or restaurants.

In addition to the determinants of cross-border purchasing, the motives of Users and Non-Users of Bavarian retail offers are also relevant. Most notably, the quality of retail offers on the German side is the most important reason for Czech customers to shop across the border. Contrary to this, however, the good offer on the Czech side is an important reason for the Non-Users. From this, it can be concluded that marketing activities that focus on high-quality offers and service on the Bavarian side must be intensified.

- Digital marketing: Information about the quality offered by local stores in Bavaria should primarily be made available via digital media and direct marketing, as Czech customers hardly use daily newspapers (see IHK Regensburg für Oberpfalz/Kelheim [35]). This must be based on an Internet merchandising strategy that best covers all important locations in East Bavaria along the border.

- Welcoming Culture: An even better welcome culture must be developed that includes not only companies but also all other stakeholders of the locality. This starts with a welcome board at the city entrance and finishes with the Czech knowledge of the staff.

This study fills a number of gaps concerning cross-border shopping, but further research is necessary. In order to increase the share of Czech customers, it is important not only to identify motives for (or against) cross-border shopping in Bavaria but also to find out how Czech customers really benefit from specific offers; for example, it is desirable to establish a joint offer of shopping and accommodation.

Thanks to technological development, Czechs increasingly perceive the worldwide issue of sustainable development as a critical one for the future of us all; however, the Czech economy only puts a marginal emphasis on this topic, and only in selected areas. Germany is way ahead of us and significantly more active than we are when it comes to following and fulfilling the 17 sustainable development goals. By way of appropriate targeting and communication of their sustainable products and supplementary activities, German retailers will achieve a competitive advantage in attracting 
Czech customers. The paper by Walker [38] has the potential to contribute to the body of tourism management, marketing, and branding scholarship. It also incorporates the varied and varying understandings about sustainable tourism that is useful to develop models for marketing/branding places with specific potentialities, which can be applied to the cross-border region. An example of best practice is laid out in a case study by Bratucu, Baltescu, Neacs, Boscor, Tierean, and Madar [39] on the implementation of sustainable development in mountain tourism in the Romanian Carpathians. The extent to which the predictions of German retailers gaining a competitive advantage for Czech customers, thanks to expanding the portfolio of sustainable products, can be tested using a destination loyalty model that introduces destination image in the form of the pillars of sustainability, as introduced by Lee and Xue [40].

Also, the planning perspective is important. The analysis in this study only provided data on sales volumes that flow from West Bohemia to Bavaria (i.e., Upper Palatinate), but the specific amount of outflowing purchasing power from Upper Palatinate to West Bohemia was not investigated in this or other studies. These figures would be important for urban planning to estimate the purchasing power balance in the border region.

This consideration must take into account the toll of the coronavirus pandemic on the economies of individual countries, including impacts on the border region.

Generally, the income situation on the Bohemian side will continue to rise due to the positive economic and employment development (Czech National Statistics). More Czech consumers will be able to benefit from the "good offer quality" (Figure 3) as rising incomes imply an increasing frequency of cross-border shopping visits (Table 10). Thus the Czech consumer potential is not only sustainable but should be stepped up by German retailers due to the rising purchasing power. Nevertheless, the closure of the border in the corona pandemic strikes retailers within the border region on both sides hardest. On the Bavarian side, grocery stores are affected first as the main target group is Czech consumers, who were mainly not allowed to leave their country. It remains to be seen how this development will change cross-border shopping activities in the long term not only from the administrative and political but also from the individual perspective, which we have tried to quantify by the indicators analyzed within the outlined logit model. This question will definitely be the subject of further research.

\section{Conclusions}

The opening up of borders in Europe not only brought a political but also an economic change for cross-border spaces. From a macro perspective, this development leads to an increasing exchange of commodities and people between countries. Employee mobility and the relocation of production are often connected to this theme. However, from a regional perspective, tourism and the retail sector also play a more important role for the coalescence of cross-border regions. The different retail offerings on the other side of the border is a considerable reason for cross-border activities. So far, countries with strong purchasing power, e.g., Switzerland or the Scandinavian countries, have been the subject of studies, but not the emerging Eastern European markets. Accordingly, this contribution focuses on cross-border shopping activities of border residents in West Bohemia and East Bavaria. Compared to previous studies on this subject, not only the reasons for Czechs purchasing in Germany are examined (motive), but also an estimate of the volume of sales is made (sales volume), as well as an analysis on the influence of the distance to the border on the purchasing decision (evidence of distance). Based on a POS and two household surveys, these three aspects of distance are examined by descriptive statistics. Finally, sociodemographic variables, as well as the distance function as explanatory variables within a logit approach model, are shown to influence the cross-border decision of West Bohemian inhabitants.

In addition to the methodical restrictions, it is important to discuss the range and transferability of the study. As not only the shopping but also the everyday behavior on both sides of the border differ, the results are limited in terms of being able to transfer them to other border regions. One main aspect not discussed, due to missing data, was the different language or language skills. According to 
the theoretical framework of Kovacs [41], this is one of the main indicators of cultural factors that affect the interregional flow, and it is also highlighted by Szytniewski et al. [9]. Furthermore, political factors influence the flow of people and goods between countries. Membership in a political union like the EU facilitates cross-border activities in general, and in retail particularly. Finally, the main and basic aspect in the context of the transfer to other border regions is the difference in purchasing power, which is great in the case of Bavaria and Bohemia (Figure 1). Thus, sufficient income is the basic requirement for economic exchange between both sides of the border.

About $46 \%$ of the respondents shop at least once a year in Germany. The main reason for cross-border activities is shopping (62\%). Czech customers, in particular, value the retail offer quality $(34 \%)$ and the attractive prices (23\%). On the other hand, a lack of time $(30 \%)$ and adequate offerings in the Czech Republic (19\%) are the most frequently mentioned reasons why people from West Bohemia do not come to Bavaria. Concerning relevant products, grocery stores and drugstores are also popular with Czech consumers, e.g., fashion and shoes. The "typical" cross-border shopper can be characterized by above-average income and an age between 30 and 59. Also, a higher proportion of women could be observed. Taking into account the frequency of visits and the average expenditure in the year, a total estimated volume of EUR 136.4 million flows from West Bohemia to retailers in Bavaria. Consumers from West Bohemia particularly target the border region within Upper Palatinate, from Marktredwitz along the A93 motorway and B22 national road to Cham. The descriptive analysis of the distance (routing distance estimated by Google API) shows that $50 \%$ of cross-border shoppers cover a distance of less than 22 kilometers, and 75\% less than 63 kilometers. Logically, the curve fit, which shows the correlation between distance and shopping frequency, shows a (negative) exponential shaping with an $\mathrm{R}^{2}$ of 0.33 . In general, the greater the distance to the border, the more disproportionately the shopping probability is reduced.

Finally, the data were transferred into a binary logit model, which predicts the decision for cross-border shopping (user vs. non-user) and identifies the most significant variables for this decision. According to this, the linear distance from the place of residence to the border represents the most important determinant, but "Income" and "Age" also have a significant impact on the cross-border shopping decision. The overall model fit with a Nagelkerke $\mathrm{R}^{2}$ value of 0.220 can be classified as mediocre to good. The overall classifying prediction percentage, using the model with the highest adaptation, rises from 53.7 percent to 68.3 percent.

The empirical results give concrete implications of how cross-border activities can be utilized. On the one hand, smaller specialist shops and service providers should benefit more from the frequency function of grocery stores. On the other hand, to use this synergy, for local providers, it is necessary that they implement joint offers in collaboration with grocery stores and also tourist facilities. Furthermore, as Czech customers prefer digital media, online marketing within the Czech Republic should be used as well as a more intensive welcome culture. The offer and accurately targeted communication of sustainable products and supplementary activities by German retailers present a future competitive advantage for Czech customers. Navarro, Maria-Encarnacion, and Mondejar Jimenez [42] state that although several authors have pointed out the difficulties of transferring the principles of sustainable development to a specific sector, there is a consensus regarding the need to carry out an analysis at a local level, using indicators as a key tool. In this regard, it becomes very apparent that there is a need for an international set of indicators that enable an assessment of the transition towards sustainability at a local level. As yet, however, there is no widely-used approach.

The results of the sales volume estimation also provide fundamental results for urban and regional planning institutions. The inflowing purchasing power from West Bohemia to East Bavaria is not only estimated as a whole but also in its spatial distribution. The increased intensity of shopping tourism will contribute to the economic development of this cross-border region and ensure its sustainability. Of course, in the next step, this should be observed in both directions.

To summarize, this study is the first contribution regarding motives, sales volume, and spatial aspects of cross-border shopping. Thus, it expands previous results in this research context. The applied 
approach could be seen as a methodical prototype which can also be transferred to other regions within Europe.

Author Contributions: Conceptualization, M.S. and D.H.; methodology, M.S. and D.H.; software, K.Š.; validation, D.H.; formal analysis, M.S.; investigation, D.H.; resources, M.S. and K.Š.; data curation, D.H.; writing—original draft preparation, D.H. and K.Š.; writing—review and editing, M.S.; visualization, D.H.; supervision, M.S.; project administration, M.S.; funding acquisition, K.Š. All authors have read and agreed to the published version of the manuscript.

Funding: This work was supported by the Faculty of Economics and Management, Czech University of Life Sciences in Prague under Grant number 20161003.

Acknowledgments: We would like to thank the anonymous reviewers for their helpful comments and suggestions for the previous version of this paper.

Conflicts of Interest: The authors declare no conflict of interest.

\section{References}

1. Krugman, P. Increasing Returns and Economic Geography. J. Political Econ. 1991, 99, 483-499. [CrossRef]

2. Cimler, P.E.; Eggers, B.; Hommerová, D.; Lochmüller, M.; Riedl, J. Der Grenzüberschreitende Besucherverkehr Nordostbayern-Westböhmen; Access Marketing Management: Weidenberg, Germany, 2014.

3. European Comission. Qualitative Study on Cross Border Shopping; European Comission: Versailles, France, 2004.

4. IHK Regensburg für Oberpfalz/Kelheim. Grenzüberschreitender Einzelhandel Zwischen Bayern und Tschechien. Studie zum Einkaufs- und Freizeitverhalten Tschechischer Besucher im Landkreis Cham. Regensburg; IHK Regensburg für Oberpfalz/Kelheim: Regensburg, Germany, 2009.

5. Bassols, N.; Fernández, J.R.C. Borders in Europe: From history to everyday life. Estud. Front. 2017, 18, 131-149. [CrossRef]

6. Dokoupil, J.; Kopp, J.; Reis, J. Zusammenfassung der Ergebnisse und Schlussfolgerungen. Der Einfluss der Tschechisch-Bayerischen Grenze auf die Natürlichen und die Sozioökonomischen Systeme; Západočeská Univerzita: Plzeň, Czech Republic, 2013.

7. Dokoupil, J.; Matušková, A.; Dittrich, J.; Kottl, B.; Roosen, J. Chování Spotřebitelů v Česko-Bavorském Pohraničí po Schengenu. In Regionální Výzkum v Česko-Německém Pohraničí; Univerzita Jan Evangelista Purkyně: Ústí nad Labem, Czech Republic, 2010.

8. Jeřábek, M.; Pohajdová, B.; Raška, P. Regionální Výzkum v Česko-Německém Pohraničí. Studia Geographica IX.; Univerzita Jana Evangelisty Purkyně: Ústí nad Labem, Czech Republic, 2010.

9. Szytniewski, B.B.; Spierings, B.; Van Der Velde, M. Socio-cultural proximity, daily life and shopping tourism in the Dutch-German border region. Tour. Geogr. 2017, 19, 63-77. [CrossRef]

10. Hampl, M. Border regions in the Czech Republic: Contemporary tendencies of development differentiation. Geografie-Sbornik ČGS 2000, 105, 241-254.

11. Ježek, J. Problémy Územniho Rozvoje Maloobchodní Sitě a Možnosti Jejich Řešení. Česká Cesta k Zákaznikiom; Vysoká Škola Evropských a Regionálních Studií: České Budějovice, Czech Republic, 2006.

12. Boom, S.; Weijschede, J.; Melissen, F.; Koens, K.; Mayer, I. Identifying stakeholder perspectives and worldviews on sustainable urban tourism development using a Q-sort methodology. Curr. Issues Tour. 2020. Early Access. [CrossRef]

13. Spilková, J. The Birth of the Czech Mall Enthusiast: The Transition of Shopping Habits from Utilitarian to Leisure Shopping. Geografie 2012, 117, 21-22. [CrossRef]

14. Teodorescu, N.; Pargaru, I.; Stancioiu, A.F.; Matei, E.; Botos, A. Modelling The Image Research Of A Tourism Destination. Amfiteatru Econ. 2014, 16, 1076-1088.

15. Bygvrå, S. The Road to the Single European Market as Seen Through the Danish Retail Trade: Cross-Border Shopping Between Denmark and Germany. Int. Rev. Retail Distrib. Consum. Res. 1998, 8, 147-164. [CrossRef]

16. Makkonen, T. Cross-border shopping and tourism destination marketing: The case of Southern Jutland, Denmark. Scand. J. Hosp. Tour. 2016, 16, 36-50. [CrossRef]

17. Spierings, B.; Van Der Velde, M. Cross-Border Differences and Unfamiliarity: Shopping Mobility in the Dutch-German Rhine-Waal Euroregion. Eur. Plan. Stud. 2013, 23, 5-23. [CrossRef] 
18. Rudolph, T.; Nagengast, L.; Nitsch, F. Einkaufstourismus Schweiz 2015; Universität St. Gallen: St. Gallen, Switzerland, 2015.

19. Timothy, D.J.; Butler, R.W. Cross-Border Shopping-A Nort American Perspective. Annu. Tour. Res. 1995, 22, 16-34. [CrossRef]

20. Sullivan, P. A comparison of cross-border shopping motivations: Canadian cross-border shoppers and US cross-border shoppers. In Proceedings of the 10th International Conference on Research in the Distributive Trades Conference, Stirling, Scotland, UK, 26-28 September 1999.

21. Mulvey, M.; Gengler, C.; Lever, M. Perspective-taking for policy-making: An analysis of Canadian cross-border shopping. NMIMS Manag. Rev. 2017, 34, 54-70.

22. Bar-Kołelis, D; Wendt, J.A. Comparison of Cross-Border Shopping Tourism Activities at the Polish and Romanian External Borders of European Union. Geogr. Pol. 2018, 91, 113-125. [CrossRef]

23. Förster, C. Cross-Border-Shopping im Bayerisch-tschechischen Grenzraum Untersucht am Beispiel der Städte Marktredwitz und; Universität Bayreuth: Bayreuth, Germany, 2007.

24. Köttl, B. Grenzüberschreitender Konsum; Nomos: München, Germany, 2014.

25. IHK Chemnitz. Studie zum Grenzüberschreitenden; IHK Chemnitz: Chemnitz, Germany, 2012.

26. IHK Dresden. Chancen für den Einzelhandel-Ergebnisse einer Befragung zum Einkaufsverhalten Tschechischer Kunden in Zittau im November 2011; IHK Dresden: Dresden, Germany, 2012.

27. IHK München für Oberbayern. Oberbayern als Einkaufs- und Tourismusziel für Österreicher; IHK München für Oberbayern: München, Germany, 2015.

28. IHK Niederbayern. Starke Handelsstandrte-Kaufkraftstromanalyse und Einzelhandelsuntersuchung 2014; IHK Niederbayern: Passau, Germany, 2015.

29. IHK Cottbus, Arbeitgeberverband Lebuser Land. Wohin der Zloty fließt_Das Konsumverhalten Polnischer Gäste in Cottbus Spree-Neiße; IHK Cottbus: Cottbus, Germany, 2015.

30. Asplund, B.M.; Friberg, R.; Wilander, F. Demand and distance: Evidence on cross-border shopping. J. Public Econ. 2007, 9, 141-157. [CrossRef]

31. Leal, A.; Lopez-Laborda, J.; Rodrigo, F. Cross-Border Shopping: A Survey. Int. Adv. Econ. Res. 2010, 16, 135-148. [CrossRef]

32. Czech Statistical Office. Population in Districts 31.12.2012; CZSO: Prague, Czech Republic, 2013.

33. MB Research. Purchasing Power at the Community Level for Czech Republic (max. $40 \mathrm{~km}$ around Border); MB Research: Nuremberg, Germany, 2014.

34. BBE. Endbericht_Studie zum Einkaufs- und Freizeitverhalten Tschechischer Besucher im Bezirk der IHK Regensburg für Oberpfalz/Kelheim; BBE: München, Germany, 2014.

35. IHK Regensburg für Oberpfalz/Kelheim. Tschechische Kunden-Chancen für Handel und Tourismus; IHK Regensburg für Oberpfalz/Kelheim: Regensburg, Germany, 2015.

36. OECD. Dataset Income Distribution and Poverty (County Level); OECD: Prague, Czech Republic, 2014.

37. Nanengast, L.; Linzmajer, M.; Boettger, T.; Rudolph, T. Emotional and Behavioral Consequences of Cross-Border Shopping. Tour. Geogr. 2016, 26, 759.

38. Walker, T.B. A Review of Sustainability, Tourism, and the Marketing Opportunity for Adopting The Cittaslow Model In Pacific Small Islands. Tour. Rev. Int. 2020, 23, 99-114. [CrossRef]

39. Bratucu, G.; Baltescu, C.A.; Neacsu, N.A.; Boscor, D.; Tierean, O.M.; Madar, A. Approaching the Sustainable Development Practices in Mountain Tourism in the Romanian Carpathians. Sustainability 2017, 9, 2051. [CrossRef]

40. Lee, S.W.; Xue, K. A model of destination loyalty: Integrating destination image and sustainable tourism. Asia Pac. J. Tour. Res. 2020, 25, 393-408. [CrossRef]

41. Kovács, A. On Borders, Border Regions and Cross-Border Retail-Trading. Sci. Pap. Univ. Pardubic. Ser. D 2013, 28, 29-42.

42. Alfaro Navarro, J.L.; Andres Martinez, M.E.; Mondejar Jimenez, J.A. An approach to measuring sustainable tourism at the local level in Europe. Curr. Issues Tour. 2020, 23, 423-437. [CrossRef]

(C) 2020 by the authors. Licensee MDPI, Basel, Switzerland. This article is an open access article distributed under the terms and conditions of the Creative Commons Attribution (CC BY) license (http://creativecommons.org/licenses/by/4.0/). 